\title{
Impact of field headlands on wheat and barley performance in a cool Atlantic climate as assessed in 40 Irish tillage fields
}

\author{
M. Ward ${ }^{1,2 \dagger}$, P.D. Forristal ${ }^{2}$, K. McDonnell ${ }^{1}$ \\ ${ }^{1}$ School of Agriculture and Food Science, University College Dublin, Belfield, Dublin 4, Ireland
}

${ }^{2}$ Teagasc, CELUP, Crops Research, Oak Park, Carlow, Ireland

Abstract

The reduction in cereal crop yields on field headlands has previously been examined in other geographical regions, with research focusing on the relationship between yield and the distance from the crop edge. Headlands are subject to greater machinery trafficking than the centre of the field and the level of traffic imposed depends on the machine size and adopted turning practice. The aim of this work was to examine the impact of turning headlands on crop performance in a survey of $\mathbf{4 0}$ field sites in Irish conditions. The headland was categorised into three distinct zones: the area next to the field edge subject to moderate traffic intensities (field edge); the main headland area of greatest turning traffic (turning) and a transition zone (transition). An in-field zone (in-field) in which no machinery turns occur was also included. The 2-year survey included sites from three regions, four soil texture classes and had crops established with plough-based systems. Crop measurements, including plant densities, shoot counts and light interception, and yields were recorded at each site and included winter barley (WB), spring barley (SB) and winter wheat (WW) crops. The yield response of each crop type varied with sample zone, region and soil texture. There were significant $(P<0.001)$ yield differences recorded between the turning area and in-field zone for all three crops. Winter barley yields were reduced by $1.3 \mathrm{t} / \mathrm{ha}$ in the turning zone compared with the in-field section, while SB and WW had yield reductions of 2.08 and 4.04 t/ha, respectively, between these two field zones.

Keywords

Crop performance $\bullet$ field margin $\bullet$ grain yields $\bullet$ headland $\bullet$ Ireland.

\section{Introduction}

The strip of land, adjacent to an arable field boundary and of a width that contains all machinery operations conducted parallel to this boundary, typically the width of the sprayer boom in cereal production, is commonly referred to as an arable field headland or the field margin, although this term can also be used for a no-crop area (Boatman \& Sotherton, 1988; Boatman, 1992; Sparkes et al., 1998a; Wilcox et al., 2000). Boatman (1992) defined this area as "the region between the outer edge of the crop and the first set of tramlines parallel to the crop edge". Sparkes et al. (1998a, 1998b) classified headlands into two groups: "turning headlands" and "nonturning headlands". Turning headlands are headlands in which machinery turns occur, resulting in potential soil structural damage and crop loss. Here, the crop rows are sown at a contrasting angle to the crop in the main field area but parallel to the field boundary. Non-turning headlands represent the remaining field headland areas.
The turning headland area can have lower yields than the midfield area (Speller et al., 1992; Cook \& Ingle, 1997; Sparkes et al., 1998b; Kuemmel, 2003). Significant variations in winter wheat (WW) yields from 0.8 to 10.2 t/ha were recorded by Wilcox et al. (2000) and 5.5 to 9.4 t/ha yields were recorded by Chaney et al. (1999). Sparkes et al. (1998a) quantified mean yield reductions for sugar beet at $26 \%$, WW at $8 \%$ and winter barley (WB) at 5\% whereas Cook and Ingle (1997) calculated the mean WW headland yield penalty at $15.6 \%$. Comparable results were obtained by Barbour et al. (2007) who documented a $10 \%$ yield reduction for soybean field headlands and a $30 \%$ yield reduction for the first combine swath of each corn field. Occasionally, yield increases were recorded at certain headland locations (Boatman \& Sotherton, 1988; Cook \& Ingle, 1997). Speller et al. (1992) attributed reduced headland yields to factors such as compaction due to trafficking by farm machinery; shading and water competition 
from hedgerows and woods; weed ingress and destruction by small grazing mammals. Although each of these factors, alone or in combination, impact on yield, machinery-induced soil compaction is considered as the predominant factor by many studies (Speller et al., 1992; Sparkes et al., 1998a; Wilcox et al., 2000). Soil underpins every cropping system and serves as the medium for plant roots to grow and produce high yielding crops in the provision of essential nutrients, water and air (Ball \& Douglas, 2003). Reduced yields are not uncommon and are often characteristic of reduced germination rates, reduced crop growth and inferior grain quality in uncontrolled traffic farming systems (Chamen et al., 2015).

Many previous studies on the impact of headlands are based on surveys of growers' fields (Boatman \& Sotherton, 1988; Boatman, 1992; Speller et al., 1992; Cook \& Ingle, 1997; Sparkes et al., 1998b; Wilcox et al., 2000). Of these studies, Speller et al. (1992), Cook and Ingle (1997) and Wilcox et al. (2000) included distance from the field boundary as a factor in the analysis. Over 2 years (1994 and 1995), Wilcox et al. (2000) surveyed $40 \mathrm{WW}$ headlands on sandy loam, clay loam and calcareous soil types. Yields were assessed by hand sampling from $0.25 \mathrm{~m}^{2}$ quadrats placed on transects at right angles from the crop edge on each field headland. Yields increased with distance in a non-linear fashion, to reach an asymptotic maximum at $30 \mathrm{~m}$ from the edge of the crop suggesting that the "headland effect" can extend a considerable distance into the field. In similar research, Speller et al. (1992) studied WW headlands by assessing crop performance at six plots located 1-26.8 $\mathrm{m}$ from the crop edge at five sites. Cook and Ingle (1997) used four sampling plots from the crop edge to a point of $20 \mathrm{~m}$ into the crop. Although these authors measured yields at set intervals into the field, these yields were not based on specific machinery patterns in the field and the studies did not document any consistent pattern apart from an overall trend of increasing yields from the field boundary to the main crop zone. Despite the fact that boundary features may cause yield reductions adjacent to them, the beneficial shelter effect of some boundaries can also prevent yield depression further into the field in certain climates (Kuemmel, 2003). This trend was reported by Kowalchuk and Jong (1995) for spring wheat in Canada, and Abdalla and Fangama (2015) for cotton, groundnuts and sorghum in Sudan. The opposite effect was documented in the UK by Sparkes et al. (1998a), where 4.4 t/ha WW yields in the outermost $9 \mathrm{~m}$ of the field or $8.1 \mathrm{t} / \mathrm{ha}$ in the unshaded regions were recorded.

Higher weed populations on field headlands can lead to weed ingress into the adjacent crops, imposing effects on the crop by competing for light, nutrients or moisture (Boatman, 1992; Marshall \& Arnold, 1995).

The literature has shown some consistency in demonstrating a general change in crop performance on headlands internationally with respect to distance from the edge of the crop. However, research to date has not considered the underlying factors due to specific traffic patterns or machinery operations associated with headland management when defining their headland sample locations. There is also no published systematic study of headland crop performance in a cooler Atlantic climatic such as Ireland which may make crop effects more likely, given the inherent nature of a higher rainfall climate, particularly if coupled with smaller sized fields and the use of larger machines. If the crop performance on headlands is impacted by machine traffic, it suggests that improved headland traffic management may be required to protect the productive capacity of these areas.

The objective of the current study was to determine the impact of zones primarily, as defined by machinery traffic, on crop establishment, growth and yield, compared with the in-field area, in a cool Atlantic climate in Ireland. It was hypothesised that headland areas near the crop boundary and subject to machine turning would have reduced crop performance and produce lower crop yields.

\section{Materials and methods}

\section{Site selection}

This study consisted of 40 cereal fields from 25 farms under conventional cultivation (plough-based) in the main cerealgrowing area of Ireland (east of a line from $53^{\circ} 54^{\prime} 13.9^{\prime \prime} \mathrm{N}$ $6^{\circ} 25^{\prime} 46.3^{\prime \prime} \mathrm{W}$ in the north-east to $52^{\circ} 06^{\prime} 43.8^{\prime \prime} \mathrm{N} 7^{\circ} 48^{\prime} 05.2^{\prime \prime} \mathrm{W}$ in the south of Ireland) (Figure 1). Fields were selected at random from a list populated following correspondence with the Teagasc advisors in the regions of interest. Teagasc is a state-funded agency in Ireland which provides research, advice and education in agriculture and food (Teagasc, 2018). Only fields cropped in cereals for at least 3 years prior to the study were selected. The trial sites were classified based on privately owned farms with a mean field size of 8.34 ha ( $n=40$, range: $1.64-37.72$ ha) growing WB, spring barley (SB) and WW. They were grown on soils with United States Department of Agriculture (USDA) (2018) texture classifications of sandy loam, loam and clay loam and with a mean elevation of 64.4 metres above sae level ( $\mathrm{m}$ a.s.I.) ( $n=40$, range: $17-125 \mathrm{~m})$. The current study was carried out over two growing seasons 2016/2017 and 2017/2018, with 20 different sites studied each year. As this was a survey of growers' fields, all of the crop management in terms of operation timing and input application were as the grower would normally apply with records retained. Study sites were classified according to soil texture, headland management practices and region. Information related to headland management and turning practices was gathered to facilitate determination of dimensions of 


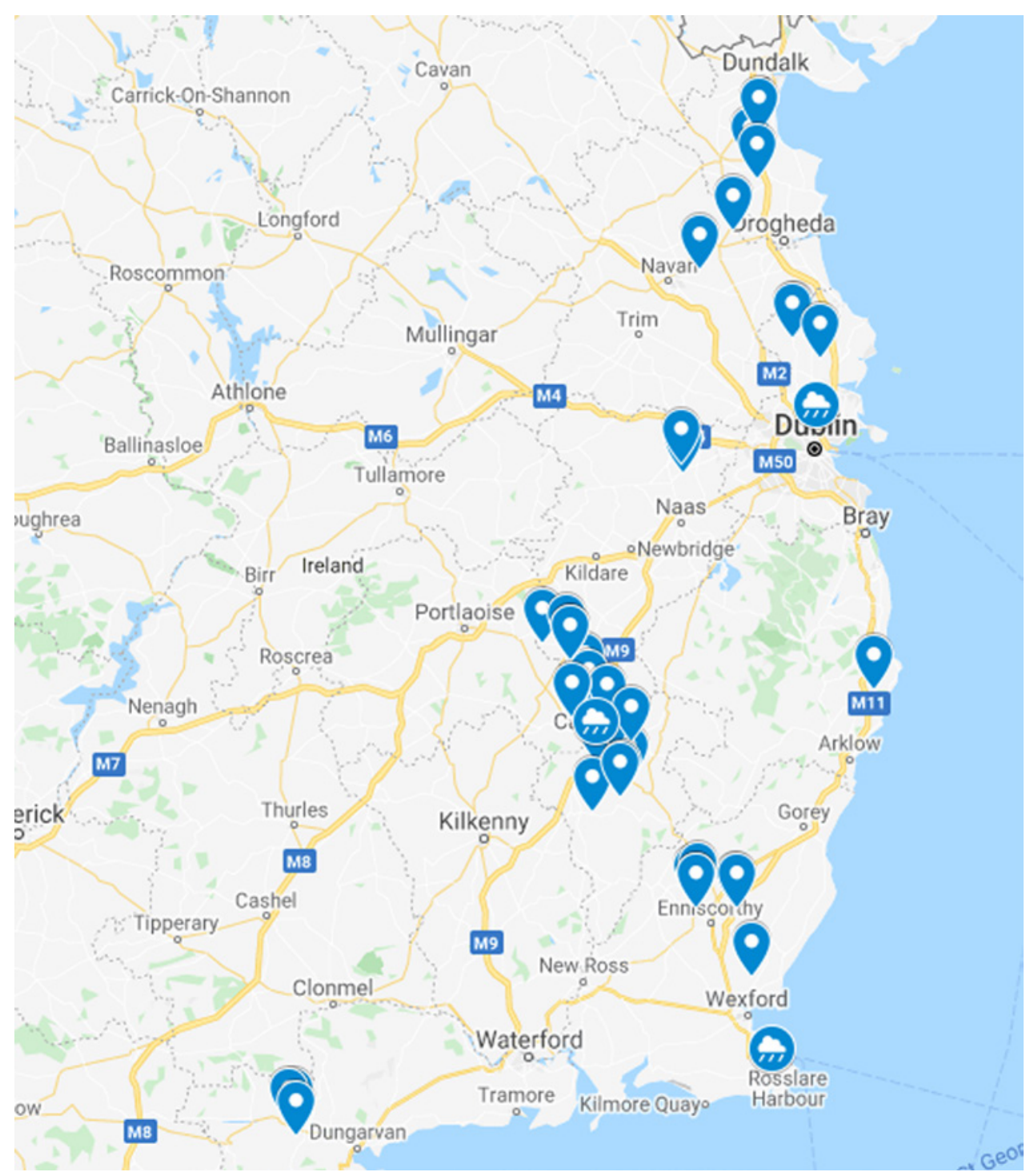

Figure 1. Geographic illustration of 40 commercial trial sites and three weather stations.

headland sample areas. The sites were allocated to one of the three regions based on proximity to local Met Éireann (Irish National Meteorological Service) weather stations: Dublin Airport (region 1), Carlow (Oak Park) (region 2) and Johnstown Castle (region 3).

\section{Study design}

At each site, a single turning headland was selected for the study and four transects (replications) were set out at right angles to the field boundary and centred between the infield tramlines (Figure 2). An approach utilising the pattern of machinery traffic to determine sample locations based on machinery traffic intensities was used. This was determined by machine operating widths, turning patterns and the overall headland turning width chosen by the operator. Four zones (three headland zones and one in-field zone) were identified: an area of moderate headland traffic next to the field edge (field edge); the main headland area of maximum headland traffic and highest axle loads where machines turn (turning); transition zone between headland and infield area (transition) and an in-field zone (in-field) which could be considered as the control for this experiment. In the most frequently encountered $24 \mathrm{~m}$ tramline system, for example, where the operator lifts all mounted equipment when the tractor is located approximately $12 \mathrm{~m}$ from the field boundary, sample points were positioned at $3 \mathrm{~m}$ from the boundary (representing a midpoint in the field edge zone), $8.5 \mathrm{~m}$ (turning zone), $16 \mathrm{~m}$ (transition zone) and $35 \mathrm{~m}$ (in-field 


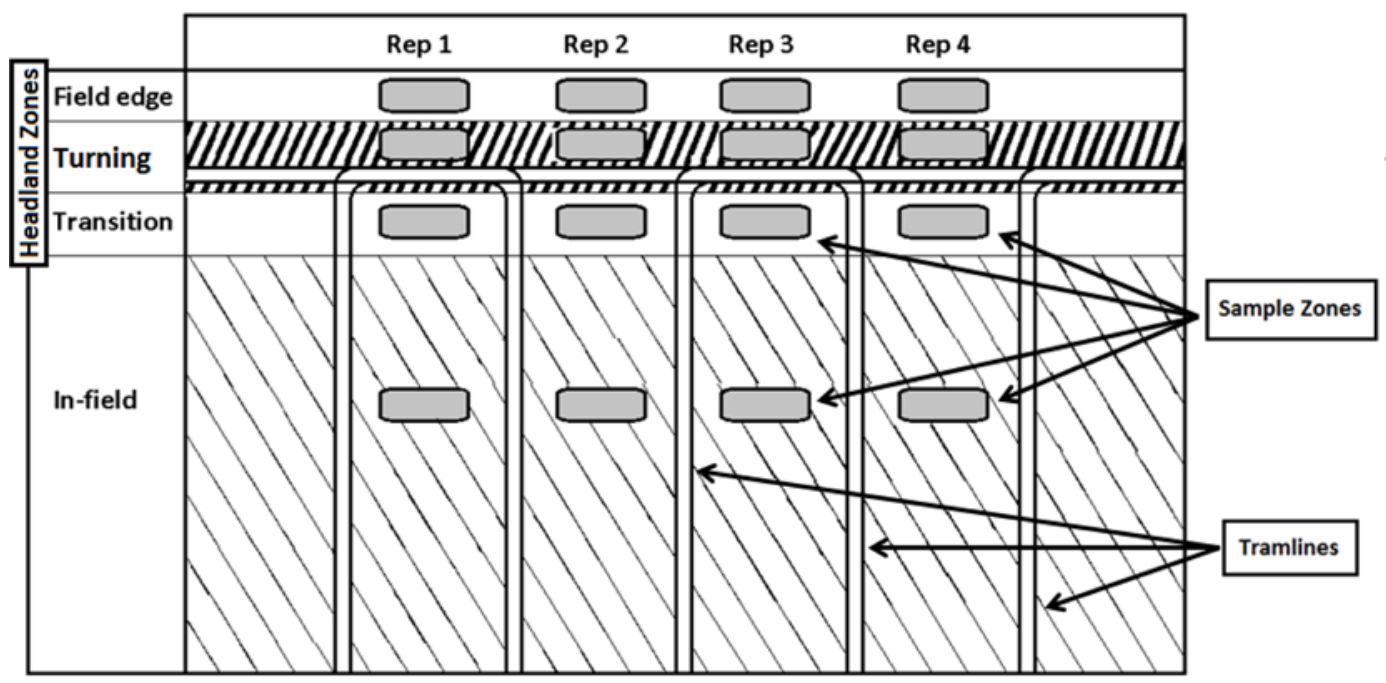

Figure 2. Illustration of the headland and in-field sample zone approach.

zone) from the field boundary along each transect. With four transects (replications), this resulted in 16 sample areas per site (Figure 2).

\section{Crop measurements}

Following plant emergence, plant population densities were determined by counting plants within quadrats. To account for the expected variability in headland areas, five quadrats, each of $0.125 \mathrm{~m}^{2}$, were placed randomly (but orientated at $90^{\circ}$ to the direction of sowing) at each sample point. This was chosen in preference to single sample quadrats used by other authors (e.g. Wilson and Aebischer (1995) used one $0.25 \mathrm{~m}^{2}$ quadrat).

Once the crops reached growth stage GS32 (Zadoks growth scale; Zadoks et al., 1974), shoot counts were conducted on 20 randomly selected plants from each headland zone. Photosynthetically active radiation (PAR) interception by the crop was determined at GS30 and GS32 (light intercepted 1 and light intercepted 2, respectively). A Sunscan Canopy Analysis System (Delta-T Devices, Cambridge, UK) was used to measure PAR above and below the canopy to calculate light interception and provide an indicator of variation in biomass levels between headland zones. Measurements were taken according to the method described by Kennedy (2015) at five randomly selected locations at each of the 16 measurement areas at each site.

\section{Calibration of hand-yield estimation technique}

As it would not have proven possible to use a plot combine to harvest individual headland samples areas at 20 different sites each year over a short harvest period, a detailed hand- harvesting system that allowed a wider sample window was used. The developed methodology was validated with a plot combine at Teagasc Oak Park prior to commencing trials, where 32 headland sample areas were assessed. Ten quadrats of $0.125 \mathrm{~m}^{2}$ were taken at each sample area to validate measurements. Samples were cut at ground level and stored in a glass house to dry after which they were threshed (Saatmeister Kurt Pelz, Maschinenbau, Germany) and cleaned (Laboratory seed winnower, type 4111.10.00, Seed Processing Holland, Enkhuizen, The Netherlands) before all yield components were weighed and dried for dry matter analysis. Thousand grain weight (TGW) was also calculated (Haldrup GC-30 automatic grain counter, Haldrup $\mathrm{GmbH}$, Ilshofen, Germany). Threshed grain yield (t/ha) was expressed at $85 \%$ dry matter; ears $/ \mathrm{m}^{2}$ and grains $/ \mathrm{m}^{2}$ were calculated using mean grain weight (MGW) and grains/ear was calculated using grain number data and ear number data. Harvest index $(\mathrm{HI})$ was also calculated. It expresses the weight of harvested grain as a percentage of total shoot dry matter (Unkovich et al., 2010).

The yields recorded with the hand sampling method tended to be greater than that with the combine due to: the smaller sample area did not include unsown tramlines; a consistent tendency to include more plants than the nominal quadrat area when placing the quadrat due to the row structure of the plants and all grains, regardless of size, were included in the final weighing. These factors would require the resulting yield figures to be corrected if they were to be used to represent the overall field yields. However, for the purpose of this study, the recorded values allow satisfactory comparison of relative yields in the outlined field zones. 


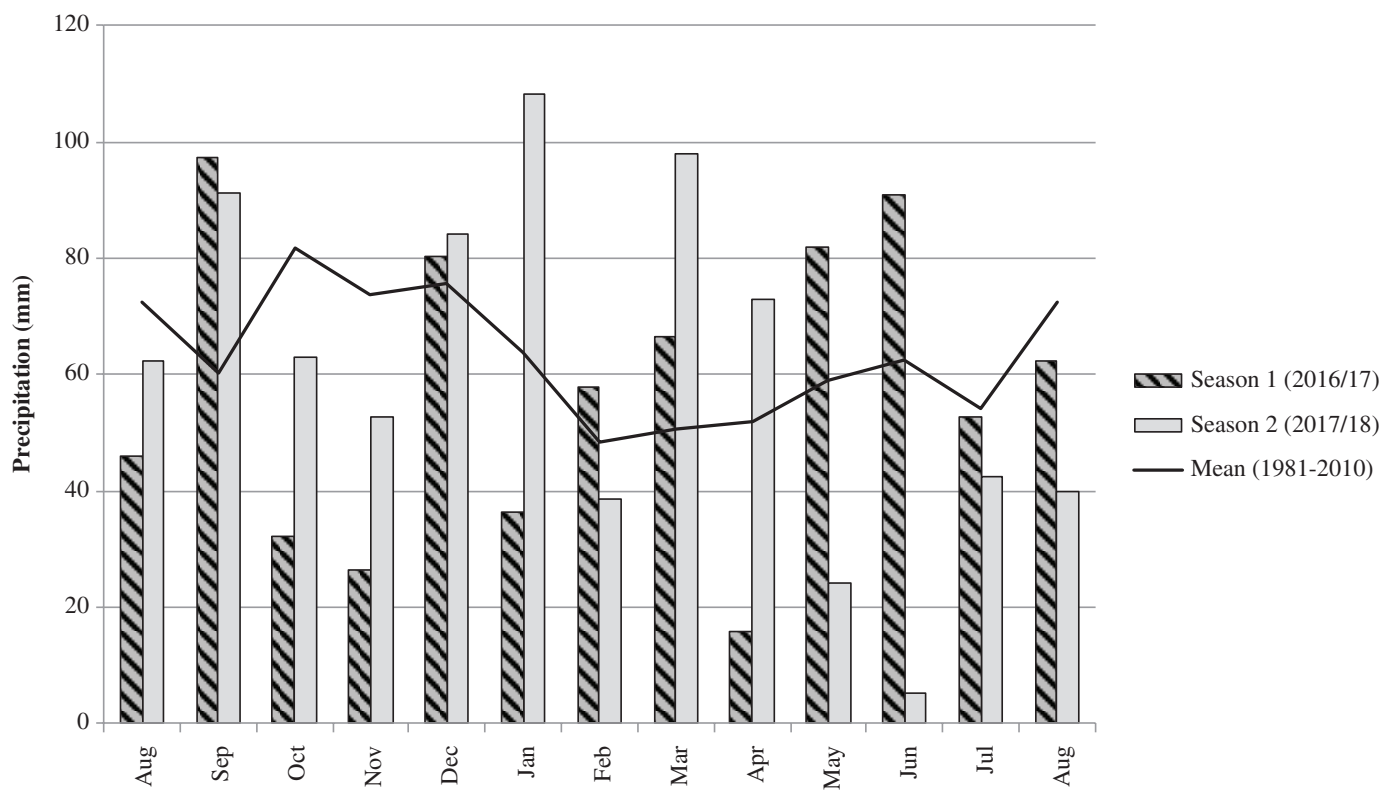

Figure 3. Monthly precipitation ( $\mathrm{mm}$ ) at Carlow (Oak Park), representing region 2, for both years of the study.

To determine an appropriate yield quadrat sample number at each measurement point, three, five and ten samples were compared in the validation studies. The standard error was decreased from 11.34 with three samples to 7.84 with five and to 6.21 with all ten samples. Five was selected as an acceptable sample number.

\section{Meteorological data}

Weather conditions over the study period did not differ substantially from the 30 year average for the first year, but the second year had a much wetter spring followed by significant drought as indicated in Figure 3 which impacted on spring cereal yields.

\section{Statistical analyses}

As each site had replicated measurements, sites could be analysed individually and as a group. Responses were analysed using a two-way analysis of variance (ANOVA) structure with blocking. The PROC GLIMMIX procedure was employed for most of the analysis in SAS 9.4 (Cary, North Carolina, USA). Both growing seasons were analysed together as different sites were used in each season precluding any option to analyse year as a factor. The two factors were headland area and site (with region and texture substituted for site in separate analyses) and the blocks were nested within the site. The analysis (a general linear model) was fitted using the mixed procedure (SAS 9.4). Means were compared after a Tukey adjustment for multiple comparisons. Residual checks were made to ensure that the assumptions of the analysis were met (normal distribution, constant variance, etc.).

\section{Results}

\section{Survey results 1: Analysis of all survey sites}

The number of sites and crop types analysed each year and their mean yields are given in Table 1. Although the use of different sites each year precludes analysis of a year effect, SB showed the greatest variability between years with WB showing very little variability. The results of the survey when all sites are analysed together are presented by crop type (Tables 2-4) with all the measured parameters included. There were significant interactions between zone and region and between zone and soil texture for many of the measured parameters in each crop. The main effects of zone, region and soil texture were highly significant for most parameters measured for all crop types. In the following sections, the interactions are considered with the appropriate main effect, but the individual interaction means are presented only for grain yield.

\section{Impact of zone on crop performance}

All three crops displayed an effect of zone on crop performance (Tables 2-4). The highest mean yields for WB, 
Table 1: Mean cereal yields ( $t / h a$ ) for each year of trials

\begin{tabular}{lcc}
\hline Crop & Year 1 $(\mathbf{t} / \mathbf{h a})(\boldsymbol{n}=\mathbf{2 0})$ & Year 2 $(\mathbf{t} / \mathbf{h a})(\boldsymbol{n}=\mathbf{2 0})$ \\
\hline WB & $11.56(n=6)$ & $11.36(n=2)$ \\
SB & $9.57(n=10)$ & $6.17(n=14)$ \\
WW & $13.35(n=4)$ & $10.36(n=4)$ \\
\hline
\end{tabular}

WB, winter barley; SB, spring barley; WW, winter wheat.

SB and WW for both years of the study were recorded at the in-field zone. The greatest headland yield reductions were between the in-field and the field edge zones for all crop types (Table 5). The yield penalty on WW sites tended to be the largest followed by SB and then WB.

Crop establishment figures for WB were the highest in the transition zone, with this area also having the most light intercepted at GS30. However, by GS32 the turning and transition zones had the highest level of growth. When harvested, the in-field sample areas had a higher yield at $12.28 \mathrm{t} / \mathrm{ha}$ than the headland areas. There was an interaction between zone and region for both SB and WW (Table 6) which showed that there was a greater response to zone in regions 1 and 3 compared with zone in region 2 for SB. In the case of WW, regions 2 and 3 had a greater response to zone than region 1 . Soil texture also had an impact on the effect of zone for SB (Table 7). On the clay loam soils, the transition zone was lower yielding relative to the other zones compared with that on the lighter textured soils.

In the case of SB, the most common crop in the survey, establishment plant density figures were generally lower in the three headland zones when contrasted with the in-field zone. This trend continued through the growth stages with the transition and in-field zones displaying higher shoot counts and more light interception than the areas next to the field edge and in the turning zone. At harvest, there was a

Table 2: Effect of zone, region and soil texture on crop establishment, indicators of growth and final yields of WB from eight survey sites (superscripts represent the Tukey analysis where values followed by the same letter are not significantly different)

\begin{tabular}{|c|c|c|c|c|c|c|c|c|c|c|}
\hline \multicolumn{11}{|c|}{ Winter Barley $(n=8)$} \\
\hline & & $\begin{array}{c}\text { Grain } \\
\text { yield (t/ha) }\end{array}$ & $\mathrm{HI}$ & $\begin{array}{c}\text { Plant } \\
\text { density } \\
\text { (plants } / \mathrm{m}^{2} \text { ) }\end{array}$ & $\begin{array}{l}\text { Shoot } \\
\text { counts } \\
\text { (n/plant) }\end{array}$ & $\begin{array}{c}\text { Light } \\
\text { intercepted } \\
1(\%)\end{array}$ & $\begin{array}{c}\text { Light } \\
\text { intercepted } \\
2(\%)\end{array}$ & TGW (g) & $\begin{array}{c}\text { Ears } / m^{2} \\
(n)\end{array}$ & $\begin{array}{c}\text { Grains/ear } \\
(n)\end{array}$ \\
\hline \multirow[t]{5}{*}{ Zone } & Field edge & $10.98^{b}$ & $0.55^{\mathrm{b}}$ & $247.40^{b}$ & $4.02^{a}$ & $0.64^{d}$ & $0.89^{b}$ & $56.06^{a}$ & $785.44^{b}$ & $26.09^{\text {ba }}$ \\
\hline & Turning & $11.45^{\mathrm{b}}$ & $0.55^{\mathrm{b}}$ & $249.95^{b}$ & $4.15^{\mathrm{a}}$ & $0.71^{b}$ & $0.93^{a}$ & $54.18^{b}$ & $831.17^{\text {ba }}$ & $25.52^{\text {ba }}$ \\
\hline & Transition & $11.33^{b}$ & $0.54^{\mathrm{b}}$ & $325.86^{a}$ & $4.05^{\mathrm{a}}$ & $0.78^{a}$ & $0.94^{a}$ & $52.35^{c}$ & $862.00^{\mathrm{a}}$ & $24.36^{b}$ \\
\hline & In-field & $12.28^{a}$ & $0.56^{\mathrm{a}}$ & $254.02^{\mathrm{b}}$ & $4.16^{\mathrm{a}}$ & $0.68^{\mathrm{c}}$ & $0.88^{b}$ & $55.99^{a}$ & $799.77^{b}$ & $28.31^{a}$ \\
\hline & DF & 72 & 72 & 72 & 72 & 72 & 72 & 72 & 72 & 72 \\
\hline \multirow[t]{3}{*}{ Region } & $1(n=4)$ & $11.12^{b}$ & $0.57^{\mathrm{a}}$ & $242.50^{\mathrm{b}}$ & $3.57^{\mathrm{b}}$ & $0.67^{b}$ & $0.93^{a}$ & $56.75^{\mathrm{a}}$ & $878.42^{a}$ & $21.54^{b}$ \\
\hline & $2(n=4)$ & $11.90^{\mathrm{a}}$ & $0.53^{\mathrm{b}}$ & $296.11^{\mathrm{a}}$ & $4.62^{\mathrm{a}}$ & $0.73^{a}$ & $0.88^{b}$ & $52.54^{b}$ & $760.77^{\mathrm{b}}$ & $30.59^{a}$ \\
\hline & DF & 90 & 90 & 90 & 90 & 90 & 90 & 90 & 90 & 90 \\
\hline Soil & Loam $(n=4)$ & $11.12^{b}$ & $0.57^{\mathrm{a}}$ & $242.50^{b}$ & $3.57^{\mathrm{b}}$ & $0.67^{b}$ & $0.93^{a}$ & $56.75^{\mathrm{a}}$ & $878.42 a$ & $21.54 b$ \\
\hline \multirow[t]{3}{*}{ texture } & $\begin{array}{l}\text { Sandy loam } \\
\qquad(n=4)\end{array}$ & $11.90^{\mathrm{a}}$ & $0.53^{\mathrm{b}}$ & $296.11^{a}$ & $4.62^{a}$ & $0.73^{a}$ & $0.88^{b}$ & $52.54^{b}$ & $760.77 b$ & $30.59 a$ \\
\hline & DF & 90 & 90 & 90 & 90 & 90 & 90 & 90 & 90 & 90 \\
\hline & & $\operatorname{Pr}>\mathrm{F}$ & $\operatorname{Pr}>\mathrm{F}$ & $\operatorname{Pr}>\mathrm{F}$ & $\operatorname{Pr}>\mathrm{F}$ & $\operatorname{Pr}>\mathrm{F}$ & $\operatorname{Pr}>\mathrm{F}$ & $\operatorname{Pr}>\mathrm{F}$ & $\operatorname{Pr}>\mathrm{F}$ & $\operatorname{Pr}>\mathrm{F}$ \\
\hline \multicolumn{2}{|l|}{ Zone } & $<0.01$ & $<0.01$ & $<0.01$ & 0.631 & $<0.01$ & $<0.01$ & $<0.01$ & $<0.01$ & 0.005 \\
\hline \multicolumn{2}{|l|}{ Site } & $<0.01$ & $<0.01$ & $<0.01$ & $<0.01$ & $<0.01$ & $<0.01$ & $<0.01$ & $<0.01$ & $<0.01$ \\
\hline \multicolumn{2}{|l|}{ Zone*site } & $<0.01$ & $<0.05$ & $<0.01$ & $<0.01$ & $<0.01$ & $<0.01$ & $<0.01$ & $<0.01$ & $<0.01$ \\
\hline \multicolumn{2}{|l|}{ Region } & $<0.01$ & $<0.01$ & $<0.01$ & $<0.01$ & $<0.01$ & $<0.01$ & $<0.01$ & $<0.01$ & $<0.01$ \\
\hline \multicolumn{2}{|c|}{ Zone*region } & 0.569 & $<0.01$ & $<0.01$ & $<0.1$ & 0.346 & $<0.01$ & $<0.1$ & $<0.01$ & 0.142 \\
\hline \multicolumn{2}{|c|}{ Soil texture } & $<0.01$ & $<0.01$ & $<0.01$ & $<0.01$ & $<0.01$ & $<0.01$ & $<0.01$ & $<0.01$ & $<0.01$ \\
\hline \multicolumn{2}{|c|}{ Zone*soil texture } & 0.569 & $<0.01$ & $<0.01$ & $<0.1$ & 0.346 & $<0.01$ & $<0.1$ & $<0.01$ & 0.142 \\
\hline
\end{tabular}


Table 3: Effect of zone, region and soil texture on crop establishment, indicators of growth and final yields of SB from 24 survey sites (superscripts represent the Tukey analysis where values followed by the same letter are not significantly different)

\begin{tabular}{|c|c|c|c|c|c|c|c|c|c|c|}
\hline \multicolumn{11}{|c|}{ Spring Barley $(n=24)$} \\
\hline & & $\begin{array}{l}\text { Grain } \\
\text { yield } \\
\text { (t/ha) }\end{array}$ & $\mathrm{HI}$ & $\begin{array}{l}\text { Establishment } \\
\text { plant density } \\
\text { (plants } / \mathrm{m}^{2} \text { ) }\end{array}$ & $\begin{array}{c}\text { Shoot } \\
\text { counts } \\
\text { (n/plant) }\end{array}$ & $\begin{array}{c}\text { Light } \\
\text { intercepted } \\
1(\%)\end{array}$ & $\begin{array}{c}\text { Light } \\
\text { intercepted } \\
2(\%)\end{array}$ & $\begin{array}{c}\text { TGW } \\
\text { (g) }\end{array}$ & $\begin{array}{l}\text { Ears/ } \\
\mathrm{m}^{2}(n)\end{array}$ & $\begin{array}{l}\text { Grains/ } \\
\text { ear }(n)\end{array}$ \\
\hline \multirow[t]{5}{*}{ Zone } & Field edge & $6.45^{d}$ & $0.58^{a}$ & $243.33^{\mathrm{cb}}$ & $3.44^{\circ}$ & $59^{\circ}$ & $75^{d}$ & $46.38^{a}$ & $675.30^{\circ}$ & $19.68^{\mathrm{a}}$ \\
\hline & Turning & $7.19^{c}$ & $0.58^{\mathrm{a}}$ & $246.51^{b}$ & $3.59^{\mathrm{bc}}$ & $60^{c}$ & $78^{c}$ & $46.46^{a}$ & $752.01^{b}$ & $19.59^{\mathrm{a}}$ \\
\hline & Transition & $8.17^{b}$ & $0.56^{c}$ & $236.46^{\mathrm{c}}$ & $3.72^{\text {ba }}$ & $73^{\mathrm{a}}$ & $88^{a}$ & $43.52^{c}$ & $896.93^{a}$ & $19.87^{\mathrm{a}}$ \\
\hline & In-field & $8.53^{a}$ & $0.57^{\mathrm{b}}$ & $256.50^{a}$ & $3.88^{\mathrm{a}}$ & $64^{\mathrm{b}}$ & $82^{b}$ & $44.70^{\mathrm{b}}$ & $896.02^{\mathrm{a}}$ & $21.11^{\mathrm{a}}$ \\
\hline & DF & 216 & 216 & 216 & 216 & 216 & 216 & 216 & 216 & 216 \\
\hline \multirow[t]{4}{*}{ Region } & $1(n=2)$ & $5.19^{\circ}$ & $0.60^{\mathrm{a}}$ & $219.82^{b}$ & $2.77^{\circ}$ & $52^{c}$ & $57^{\circ}$ & $45.36^{b}$ & $625.09^{c}$ & $16.99^{b}$ \\
\hline & $2(n=13)$ & $7.25^{b}$ & $0.56^{\circ}$ & $224.75^{b}$ & $3.85^{\mathrm{a}}$ & $66^{a}$ & $85^{\mathrm{a}}$ & $43.65^{c}$ & $748.17^{\mathrm{b}}$ & $21.64^{a}$ \\
\hline & $3(n=9)$ & $8.61^{a}$ & $0.58^{\mathrm{b}}$ & $281.72^{\mathrm{a}}$ & $3.58^{\mathrm{b}}$ & $63^{b}$ & $81^{b}$ & $47.58^{\mathrm{a}}$ & $927.23^{a}$ & $18.46^{b}$ \\
\hline & DF & 279 & 279 & 279 & 279 & 279 & 279 & 279 & 279 & 279 \\
\hline Soil & Clay loam $(n=6)$ & $8.71^{\mathrm{a}}$ & $0.59 a$ & $287.63^{\mathrm{a}}$ & $3.45^{\mathrm{b}}$ & $57^{c}$ & $74^{\mathrm{c}}$ & $46.67^{\mathrm{a}}$ & $968.46^{a}$ & $17.99^{\mathrm{b}}$ \\
\hline \multirow[t]{4}{*}{ texture } & $\operatorname{Loam}(n=6)$ & $8.31^{b}$ & $0.56^{\mathrm{c}}$ & $224.57^{b}$ & $4.20^{\mathrm{a}}$ & $70^{\mathrm{a}}$ & $88^{\mathrm{a}}$ & $46.15^{\mathrm{a}}$ & $792.12^{\mathrm{b}}$ & $21.05^{\mathrm{a}}$ \\
\hline & $\begin{array}{l}\text { Sandy Loam } \\
\qquad(n=12)\end{array}$ & $6.66^{c}$ & $0.57^{\mathrm{b}}$ & $235.30^{\mathrm{b}}$ & $3.49^{b}$ & $64^{\mathrm{b}}$ & $81^{b}$ & $44.12^{\mathrm{b}}$ & $729.84^{c}$ & $20.61^{a}$ \\
\hline & DF & 279 & 279 & 279 & 279 & 279 & 279 & 279 & 279 & 279 \\
\hline & & $\mathrm{Pr}>\mathrm{F}$ & $\mathrm{Pr}>\mathrm{F}$ & $\operatorname{Pr}>\mathrm{F}$ & $\operatorname{Pr}>\mathrm{F}$ & $\operatorname{Pr}>\mathrm{F}$ & $\operatorname{Pr}>\mathrm{F}$ & $\operatorname{Pr}>\mathrm{F}$ & $\operatorname{Pr}>\mathrm{F}$ & $\operatorname{Pr}>\mathrm{F}$ \\
\hline \multicolumn{2}{|l|}{ Zone } & $<0.01$ & $<0.01$ & $<0.01$ & $<0.01$ & $<0.01$ & $<0.01$ & $<0.01$ & $<0.01$ & 0.310 \\
\hline \multicolumn{2}{|l|}{ Site } & $<0.01$ & $<0.01$ & $<0.01$ & $<0.01$ & $<0.01$ & $<0.01$ & $<0.01$ & $<0.01$ & $<0.01$ \\
\hline \multicolumn{2}{|c|}{ Zone*site } & $<0.01$ & $<0.01$ & $<0.01$ & $<0.01$ & $<0.01$ & $<0.01$ & $<0.01$ & $<0.01$ & 0.885 \\
\hline \multicolumn{2}{|l|}{ Region } & $<0.01$ & $<0.01$ & $<0.01$ & $<0.01$ & $<0.01$ & $<0.01$ & $<0.01$ & $<0.01$ & $<0.01$ \\
\hline \multicolumn{2}{|c|}{ Zone*region } & $<0.05$ & $<0.05$ & 0.659 & 0.330 & 0.240 & $<0.01$ & $<0.01$ & 0.579 & 0.830 \\
\hline \multicolumn{2}{|c|}{ Soil texture } & $<0.01$ & $<0.01$ & $<0.01$ & $<0.01$ & $<0.01$ & $<0.01$ & $<0.01$ & $<0.01$ & $<0.01$ \\
\hline \multicolumn{2}{|c|}{ Zone*soil texture } & $<0.05$ & $<0.01$ & 0.421 & $<0.01$ & $<0.01$ & $<0.01$ & $<0.01$ & 0.463 & 0.983 \\
\hline
\end{tabular}

significant difference between each of the four areas with the in-field zone yielding 1.32 times the yield of area next to the field edge. This yield response was mediated by the combined effects of region with zone and soil texture with zone (Table 2). There was a positive linear relationship between grain yields $(y)$ and ears $/ \mathrm{m}^{2}(x)$ for SB $(y=0.008 x+$ 1.1396, $\left.R^{2}=0.72\right)$. The relationship was not as well-defined for the other two crops.

Post full crop emergence, the transition zone had the highest plant densities for WW. However, the in-field zone produced the highest number of shoots. The area next to the field edge produced the lowest number of shoots and had the lowest light interception readings at both GS30 and GS32. This trend continued right up to harvest, when, this area located near to the field edge was the lowest yielding area, followed by the turning area, with the transition and in-field parts yielding the most.

\section{Impact of region on crop performance}

Region had a significant impact on crop performance for all of the crops evaluated (Tables 2-4). Winter barley was grown in two regions and crops grown in region 2 had better establishment plant densities, higher shoot counts, more light intercepted at GS30 and higher yields than crops grown in region 1 . The region effect was larger for $S B$ with region 1 having lower plant densities and growth parameters, resulting in a much lower yield. Despite higher plant densities and yields recorded for SB grown in region 2, measurements differed 
Table 4: Effect of zone, region and soil texture on crop establishment, indicators of growth and final yields of WW from eight survey sites (superscripts represent the Tukey analysis where values followed by the same letter are not significantly different)

\begin{tabular}{|c|c|c|c|c|c|c|c|c|c|c|}
\hline \multicolumn{11}{|c|}{ Winter Wheat $(n=8)$} \\
\hline & & $\begin{array}{c}\text { Grain } \\
\text { yield (t/ha) }\end{array}$ & $\mathrm{HI}$ & $\begin{array}{l}\text { Establishment } \\
\text { plant density } \\
\left.\text { (plants } / \mathrm{m}^{2}\right)\end{array}$ & $\begin{array}{c}\text { Shoot } \\
\text { counts } \\
\text { (n/plant) }\end{array}$ & $\begin{array}{c}\text { Light } \\
\text { intercepted } \\
1(\%)\end{array}$ & $\begin{array}{c}\text { Light } \\
\text { intercepted } \\
2(\%)\end{array}$ & $\begin{array}{c}\text { TGW } \\
\text { (g) }\end{array}$ & $\begin{array}{l}\text { Ears/ } \\
\mathrm{m}^{2}(n)\end{array}$ & $\begin{array}{l}\text { Grains/ } \\
\text { ear }(n)\end{array}$ \\
\hline \multirow[t]{5}{*}{ Zone } & Field edge & $9.31^{\mathrm{c}}$ & $0.56^{\mathrm{a}}$ & $232.18^{\mathrm{cb}}$ & $2.22^{\mathrm{c}}$ & $70^{c}$ & $78^{c}$ & $45.01^{\mathrm{a}}$ & $430.45^{c}$ & $45.62^{\mathrm{c}}$ \\
\hline & Turning & $11.73^{b}$ & $0.56^{\mathrm{a}}$ & $252.58^{\mathrm{b}}$ & $2.58^{\mathrm{b}}$ & $78^{b}$ & $86^{\text {ba }}$ & $45.49^{a}$ & $468.91^{b}$ & $51.48^{\text {ba }}$ \\
\hline & Transition & $13.02^{\mathrm{a}}$ & $0.56^{\mathrm{a}}$ & $295.91^{a}$ & $2.42^{\mathrm{b}}$ & $80^{\mathrm{a}}$ & $87^{a}$ & $45.37^{a}$ & $533.68^{\mathrm{a}}$ & $50.61^{b}$ \\
\hline & In-field & $13.35^{\mathrm{a}}$ & $0.57^{\mathrm{a}}$ & $229.76^{c}$ & $2.78^{a}$ & $76^{\mathrm{b}}$ & $85^{\mathrm{b}}$ & $45.32^{\mathrm{a}}$ & $523.76^{a}$ & $53.77^{\mathrm{a}}$ \\
\hline & d.f. & 72 & 72 & 72 & 72 & 72 & 72 & 72 & 72 & 72 \\
\hline \multirow[t]{4}{*}{ Region } & $1(n=5)$ & $11.37^{b}$ & $0.58^{\mathrm{a}}$ & $251.16^{a}$ & $2.32^{b}$ & $78^{\mathrm{b}}$ & $79^{c}$ & $43.67^{c}$ & $476.14^{b}$ & $51.61^{a}$ \\
\hline & $2(n=1)$ & $12.81^{a}$ & $0.53^{\mathrm{b}}$ & $229.13^{a}$ & $2.82^{\mathrm{a}}$ & $82^{\mathrm{a}}$ & $99^{a}$ & $50.93^{a}$ & $480.40^{b}$ & $48.29^{b}$ \\
\hline & $3(n=2)$ & $12.60^{\mathrm{a}}$ & $0.53^{\mathrm{b}}$ & $267.97^{\mathrm{a}}$ & $2.79^{\mathrm{a}}$ & $66^{c}$ & $88^{\mathrm{b}}$ & $46.55^{\mathrm{b}}$ & $526.25^{\mathrm{a}}$ & $48.33^{b}$ \\
\hline & d.f. & 87 & 87 & 87 & 87 & 87 & 87 & 87 & 87 & 87 \\
\hline Soil & Loam $(n=7)$ & $11.72^{b}$ & $0.57^{a}$ & $255.96^{a}$ & $2.45^{\mathrm{b}}$ & $75^{b}$ & $82^{b}$ & $44.50^{\mathrm{b}}$ & $490.46^{a}$ & $50.67^{a}$ \\
\hline \multirow[t]{3}{*}{ texture } & $\begin{array}{l}\text { Sandy loam } \\
\qquad(n=1)\end{array}$ & $12.81^{a}$ & $0.53^{b}$ & $229.12^{\mathrm{a}}$ & $2.82^{\mathrm{a}}$ & $82^{a}$ & $99^{a}$ & $50.93^{a}$ & $480.40^{\mathrm{a}}$ & $48.29^{a}$ \\
\hline & d.f. & 90 & 90 & 90 & 90 & 90 & 90 & 90 & 90 & 90 \\
\hline & & $\operatorname{Pr}>\mathrm{F}$ & $\operatorname{Pr}>\mathrm{F}$ & $\operatorname{Pr}>\mathrm{F}$ & $\operatorname{Pr}>\mathrm{F}$ & $\operatorname{Pr}>\mathrm{F}$ & $\operatorname{Pr}>\mathrm{F}$ & $\operatorname{Pr}>\mathrm{F}$ & $\mathrm{Pr}>\mathrm{F}$ & $\mathrm{Pr}>\mathrm{FF}$ \\
\hline \multicolumn{2}{|l|}{ Zone } & $<0.01$ & 0.211 & $<0.01$ & $<0.01$ & $<0.01$ & $<0.01$ & 0.672 & $<0.01$ & $<0.01$ \\
\hline \multicolumn{2}{|l|}{ Site } & $<0.01$ & $<0.01$ & $<0.01$ & $<0.01$ & $<0.01$ & $<0.01$ & $<0.01$ & $<0.01$ & $<0.01$ \\
\hline \multicolumn{2}{|l|}{ Zone*site } & $<0.01$ & $<0.01$ & $<0.01$ & $<0.01$ & $<0.01$ & $<0.01$ & $<0.01$ & $<0.01$ & $<0.01$ \\
\hline \multicolumn{2}{|l|}{ Region } & $<0.01$ & $<0.01$ & $<0.1$ & $<0.01$ & $<0.01$ & $<0.01$ & $<0.01$ & $<0.01$ & $<0.01$ \\
\hline \multicolumn{2}{|c|}{ Zone*region } & $<0.01$ & $<0.01$ & $<0.05$ & $<0.01$ & $<0.01$ & $<0.1$ & 0.514 & 0.758 & $<0.01$ \\
\hline \multicolumn{2}{|c|}{ Soil texture } & $<0.01$ & $<0.01$ & $<0.1$ & $<0.01$ & $<0.01$ & $<0.01$ & $<0.01$ & 0.534 & $<0.1$ \\
\hline \multicolumn{2}{|c|}{ Zone*soil texture } & 0.139 & 0.386 & 0.598 & 0.202 & $<0.01$ & $<0.1$ & 0.965 & 0.636 & 0.268 \\
\hline
\end{tabular}

Table 5: Percentage grain yield difference between in-field and headland zones

\begin{tabular}{lcccc}
\hline Zone & $\begin{array}{c}\text { WB } \\
(n=8)\end{array}$ & $\begin{array}{c}\text { SB } \\
(n=24)\end{array}$ & $\begin{array}{c}\text { WW } \\
(\boldsymbol{n}=\mathbf{8})\end{array}$ & $\begin{array}{c}\text { All crops } \\
(\boldsymbol{n}=\mathbf{4 0})\end{array}$ \\
\cline { 2 - 5 } & \multicolumn{5}{c}{ \% less than in-field zone for grain yield } \\
\hline Field edge & 11 & 24 & 30 & 22 \\
Turning & 7 & 14 & 12 & 11 \\
Transition & 8 & 4 & 2 & 5 \\
\hline
\end{tabular}

little from region 3 for mid-season growth. Although region 1 had too few sites to allow valid comparisons, statistically significant differences were recorded between regions 2 and 3 for yield and all indicators of crop growth. A zone and region interaction was recorded for SB and WW (Table 6). Region 3 had the greatest response to zone with both SB and WW, followed by region 1 for SB and region 2 in the case of WW. SB grown in region 3 had a $28 \%$ yield reduction between the in-field zone and that next to the field edge, with $5 \%$ and $21 \%$ yield reductions recorded between the same zones for regions 1 and 2, respectively. Despite region 2 showing the lowest mean yield reduction for the area next to the field edge, it showed the greatest reduction between in-field and turning zones of $17 \%$ for all three regions.

In the case of WW, when the region with only one site was excluded (region 2), the mean yield difference between wheat grown in regions 1 and 3 equated to $1.23 \mathrm{t} /$ ha. Crops in region 3 produced higher yields and had higher plant densities, shoot counts, TGW and ears $/ \mathrm{m}^{2}$ but fewer grains/ear. A 30\% yield reduction in WW yields was documented between the in-field sample zone and the area next to the field edge. 
Table 6: The impact of zone and region on cereal yields (t/ha)

\begin{tabular}{|c|c|c|c|c|c|c|c|}
\hline \multirow[t]{2}{*}{ Crop } & \multirow[t]{2}{*}{ Zone } & \multicolumn{2}{|c|}{ Region 1} & \multicolumn{2}{|c|}{ Region 2} & \multicolumn{2}{|c|}{ Region 3} \\
\hline & & (t/ha) & $\begin{array}{l}\% \text { different to } \\
\text { in-field zone }\end{array}$ & (t/ha) & $\begin{array}{l}\% \text { different to } \\
\text { in-field zone }\end{array}$ & (t/ha) & $\begin{array}{l}\% \text { different to } \\
\text { in-field zone }\end{array}$ \\
\hline \multirow{6}{*}{$\begin{array}{l}\text { Spring } \\
\text { Barley } \\
(n=24)\end{array}$} & & \multicolumn{2}{|c|}{$(n=2)$} & \multicolumn{2}{|c|}{$(n=13)$} & \multicolumn{2}{|c|}{$(n=9)$} \\
\hline & Field edge & 4.30 & -25 & 6.33 & -21 & 7.11 & -28 \\
\hline & Turning & 5.08 & -12 & 6.70 & -17 & 8.37 & -15 \\
\hline & Transition & 5.60 & -3 & 7.92 & -1 & 9.11 & -8 \\
\hline & In-field & 5.76 & - & 8.04 & - & 9.87 & - \\
\hline & S.E.M & 0.36 & - & 0.14 & - & 0.17 & - \\
\hline & & \multicolumn{2}{|c|}{$(n=5)$} & \multicolumn{2}{|c|}{$(n=1)$} & \multicolumn{2}{|c|}{$(n=2)$} \\
\hline \multirow{5}{*}{$\begin{array}{l}\text { Winter } \\
\text { Wheat } \\
(n=8)\end{array}$} & Field edge & 9.51 & -25 & 9.45 & -36 & 8.74 & -40 \\
\hline & Turning & 10.81 & -14 & 13.63 & -7 & 13.09 & -10 \\
\hline & Transition & 12.53 & -1 & 13.42 & -9 & 14.06 & -3 \\
\hline & In-field & 12.61 & - & 14.73 & - & 14.51 & - \\
\hline & S.E.M & 0.26 & - & 0.58 & - & 0.41 & - \\
\hline
\end{tabular}

Table 7: Impact of zone and soil texture on spring barley yields (t/ha)

\begin{tabular}{|c|c|c|c|c|c|c|}
\hline \multicolumn{7}{|c|}{ Spring Barley $(n=24)$} \\
\hline \multirow[t]{2}{*}{ Zone } & \multicolumn{2}{|c|}{ Clay loam (t/ha) $(n=6)$} & \multicolumn{2}{|c|}{ Loam (t/ha) $(n=6)$} & \multicolumn{2}{|c|}{ Sandy loam (t/ha) $(n=12)$} \\
\hline & (t/ha) & $\begin{array}{l}\% \text { different to } \\
\text { in-field zone }\end{array}$ & (t/ha) & $\begin{array}{l}\% \text { different to } \\
\text { in-field zone }\end{array}$ & (t/ha) & $\begin{array}{l}\text { \% different to } \\
\text { in-field zone }\end{array}$ \\
\hline Field edge & 7.59 & -23 & 7.04 & -23 & 5.59 & -26 \\
\hline Turning & 8.58 & -13 & 7.77 & -15 & 6.21 & -18 \\
\hline Transition & 8.78 & -11 & 9.27 & 1 & 7.31 & -3 \\
\hline In-field & 9.89 & - & 9.17 & - & 7.54 & - \\
\hline S.E.M & 0.21 & - & 0.21 & - & 0.15 & - \\
\hline
\end{tabular}

\section{Impact of soil texture on crop performance}

Soil texture had an effect on crop performance for all the surveyed cereal types (Tables 2-4) with a significant sample zone and soil texture interaction observed for SB grain yield (Table 7). There were no sample zone by soil texture yield interactions for WB and WW. All three crops were grown on soils of sandy loam and loam soil textures. Yields varied from 6.66 to $8.31 \mathrm{t} /$ ha for SB on sandy loam and loam soils, respectively, whereas they varied from 12.81 to $11.72 \mathrm{t} / \mathrm{ha}$ for the same soils with WW crops. Where WB was grown on sandy loam soils, higher establishment plant densities, shoot counts, better early season growth (GS30) and higher yields were recorded when contrasted with the same crops grown on the loam soils. The same result was observed for SB plant densities but higher shoot counts, indicators of crop growth and grain quality were recorded for the loam soils over the sandy loam soils.

\section{Survey results 2: The number of sites showing significant effects}

There was a significant zone by site interaction for grain yield $(P<0.001)$ for all three crops. A summary of sites where significant responses to each indicator of crop growth occurred is outlined in Table 8. Six out of the nine measured indicators of crop growth were significantly impacted in greater than $50 \%$ of sites. For grain yield, 33 out of the 40 
Table 8: Number of sites from the survey of Irish tillage field headlands showing zone effects on crop growth and yield parameters where zone by site interactions were significant

\begin{tabular}{lcc}
\hline Crop parameter & $\begin{array}{c}\text { Total no. of } \\
\text { sites with a } \\
\text { zone effect }(\boldsymbol{n})\end{array}$ & $\begin{array}{c}\text { \% of sites } \\
\text { with a zone } \\
\text { effect (\%) }\end{array}$ \\
\hline Grain yield & 33 & 83 \\
Establishment plant density & 28 & 70 \\
Shoot counts & 22 & 55 \\
Light interception at GS30 & 36 & 90 \\
Light interception at GS32 & 29 & 74 \\
TGW & 12 & 30 \\
Ears/m² & 24 & 60 \\
Grains/ear & 7 & 18 \\
HI & 19 & 48 \\
\hline
\end{tabular}

$\mathrm{HI}$, harvest index.

sites had a significant $(P<0.05)$ zone effect. Similarly large numbers of sites displayed highly significant $(P<0.001)$ zone effects for plant density, shoot counts, light interception at GS30, light interception at GS32 and ear $/ \mathrm{m}^{2}$. There was only a zone effect observed at $30 \%$ of sites for TGW and $18 \%$ of sites for grains/ear.

When looking at the number of sites where a significant response was found, the area next to the field edge produced the lowest grain yields at $73 \%$ (29 of the 40 sites) of the sites. The turning area and transition zones produced the lowest grain yields for $15 \%$ (six sites) and $13 \%$ (five sites) of the survey sites, respectively. The in-field zone tended to be the highest yielding zone and did not produce the lowest mean grain yields at any of the 40 sites (Table 9). At two-third of sites, a $20 \%$ or greater yield reduction from the in-field zone to the area next to the field edge was recorded. This increased to $90 \%$ of the sites having a $20 \%$ or greater reduction from the in-field zone compared with the area next to the field edge or the turning zone.

Table 9: Number of sites where specific headland zones had the lowest yield, by crop type

\begin{tabular}{lcccc}
\hline Zone & $\begin{array}{c}\text { Number of sites } \\
\text { with lowest zone } \\
\text { yield (all crops) }(\boldsymbol{n})\end{array}$ & $\begin{array}{c}\text { WB } \\
(\boldsymbol{n}=\mathbf{8})\end{array}$ & $\begin{array}{c}(\boldsymbol{n}) \\
(\boldsymbol{n}=\mathbf{2 4}) \\
(\boldsymbol{n})\end{array}$ & $\begin{array}{c}\text { WW } \\
(\boldsymbol{n}=\mathbf{8}) \\
(\boldsymbol{n})\end{array}$ \\
\hline Field edge & 29 & 4 & 17 & 8 \\
Turning & 6 & 0 & 6 & 0 \\
Transition & 5 & 4 & 1 & 0 \\
In-field & 0 & 0 & 0 & 0 \\
\hline
\end{tabular}

\section{Discussion}

The unique aspects of this study are:

1. It uses an approach where headland zones are determined by traffic patterns as influenced by implement size, bout widths and turning techniques and these are compared with an in-field area. This allows the zone impact on crop performance to be better defined than in previous studies that focused on developing a relationship between distances from the field boundary (Speller et al., 1992; Cook \& Ingle, 1997; Wilcox et al., 2000).

2. It is the first study of its kind to quantify the impact of headlands on crop performance in an Irish setting with a cool Atlantic climate and relatively small-sized fields.

The results clearly indicate that crop performance is impacted by the headlands and the zone in which it is grown. For WB, SB and WW in the current paper, performance in the in-field zone was either better than or as good as the best of all the other zones. Equally, for all the crops, there was a grain yield reduction in the areas next to the field boundaries when compared with that recorded in the in-field zones. However, in the transition parts of the headland, variability in crop performance depended on crop type.

In the case of WB, all of the headland-specific sample zones (area next to the field edge, turning area and transition zone) produced similar grain yields, and all were less than the infield yield, although the transition zone had much higher establishment plant densities than that found next to the field edge or at the turning zone. The greatest in-season growth as indicated by light interception was documented at the turning and transition zones, but while this resulted in more ears $/ \mathrm{m}^{2}$ than the in-field zone, fewer grains/ear contributed to lower grain yields than the in-field zone. The inability of the crop to produce the highest yields from a high number of ears $/ \mathrm{m}^{2}$ in the turning and transition zones might be explained by the fact that these numbers were as a result of higher establishment rates, due to consolidation and more cultivation in the turning area, and excess seeding in the transition area, rather than being indicators of better plant production as often noted in other experiments (Kennedy et al., 2017).

Mean SB grain yields differed significantly between each zone with yields declining from the in-field zone to the area next to the field edge across all three regions. Unlike for WB, the number of ears produced per $\mathrm{m}^{2}$ for SB was the primary driver of the yield differences recorded between sample areas next to the field edge, turning area and transition zones. This was preceded by similar differences in growth as indicated by light interception at these areas with the difference between 
the transition and in-field zones strongly underpinned by a combination of TGW and grains/ear. Similar to WB, ears $/ \mathrm{m}^{2}$ is usually the primary yield determining factor. The results from the current research indicate that other factors related to headland zones areas may have contributed to the grain yield differences where similar ears $/ \mathrm{m}^{2}$ were recorded. Wilson (1986) noted the contrasting nature of farming operations on field headlands when analysed next to those practised in the main in-field zone. They are typically cultivated, sown, sprayed and harvested in a pattern different from that of the main part of the field and this is considered in the zone sample approach developed for the current study.

There was a significant progression in grain yields for WW from the field edge to the transition zone with no significant difference recorded between the transition and in-field zones. The transition zone had higher establishment plant densities, most likely linked with overlapped sowing operations in this transition zone. This also resulted in the transition zone having greater early season growth. These yield differences contributed to the differences in both ears $/ \mathrm{m}^{2}$ and grains/ear. Although the in-field zone had higher numbers of grains/ear than the transition zone, it did not result in higher yields.

Previous researchers (Speller et al., 1992; Cook \& Ingle, 1997; Wilcox et al., 2000) indicated differences between headland and in-field crop performance and a progressive relationship between crop performance and distance from the edge of the crop. The current work indicates that the cause of the yield variation is likely to be multifactorial. Despite the turning area representing the area of greatest machinery traffic, the area next to the field edge for SB and WW yielded significantly less, indicating that traffic alone is not the sole cause of the variability. However, it is worth noting that traffic is the main feature of the turning area and this area returned consistently poorer yields than that found in the in-field zone. As uniform seeding rates were applied to the whole field with the exception of some overlapped sowing runs in the transition zone, the lower plant densities would indicate that the area next to the field edge is perhaps an area of lower establishment and overall reduced crop performance. This is supported by lower shoot counts and levels of light interception. When the area next to the field edge is contrasted with the in-field zone, it supports greater traffic intensities than the in-field zone and may be subject to many potential edge effects contributing to a reduction in grain yields such as compaction (Merrington et al., 2006; Nyéki et al., 2013), shading (Sparkes et al., 1998a), input variability (Schmitz et al., 2014), weed ingress (Marshall \& Arnold, 1995) and competition from margin flora (Cook \& Ingle, 1997). Sparkes et al. (1998a) documented areas of depressed yields around headland tramlines associated with soil compaction. Extensive variability in crop performance from establishment plant densities right through to final grain yields was recorded at the transition zone for both SB and WB.
At this location, there are a number of potentially confounding factors that can impact on crop performance including nonuniform input applications of seed, fertiliser or chemicals; overlapped soil cultivation runs and additional machinery traffic when compared with the in-field zone. Even though this work allowed the cumulative effect of all these factors to be measured, it did not allow the contribution of the individual components to be quantified, as this would be more efficiently carried out by targeted field trials rather than using a survey. The zone effect was influenced by both region and soil texture in the current study. The interaction between zone and region differed between crop types with region 3 displaying the greatest impact on grain yields between zones for SB and WW. A trend that emerged from the SB data was the higher yields on heavier soils (clay loam and loam) likely due to better moisture conservation in the dry conditions of 2018. Despite the absence of a significant sample zone*soil texture interaction for WB and WW, trends were evident. The opposite trend to SB was noted for WB and WW, where the lighter soils (sandy loams) outperformed the fine textured soils (loams). The pattern of different crops responding differently to soil texture has been recorded for barley (Kristoffersen \& Riley, 2005) and wheat (He et al., 2014). According to He et al. (2014), soil texture influences crop productivity because of its direct effect on soil water and complex interactions with other environmental factors.

The impact of headlands on crop performance in a cool Atlantic climate such as Ireland with relatively small-sized fields clearly indicated by the sample zone effects is presented. However, the headland zone response on individual farms differs as evidenced by the interaction between zone and site. A zone effect occurred at the majority of sites (33 out of 40), indicating the widespread occurrence of this effect. The ranking of zones in terms of the impact on crops varied between sites where the area next to the field edge produced the lowest grain yields at $73 \%$ of sites whereas locations at the turning or transition zone produced the lowest grain yields at $27 \%$ of sites. This emphasises the benefit of the zone approach adopted in this research and offers scope for future research to elucidate the management impacts. The results do not support the hypothesis where zones of maximum headland traffic (the turning area) were expected to produce the lowest cereal crop yields and indicators of crop performance.

This research confirms that zones were defined by machinery traffic impact on crop performance. Options to reduce this include reducing axle loads, ground pressures and traffic densities on headlands. Further work is required to investigate the range of causes such as compaction (Nyéki et al., 2013), shading, weed ingress, grazing by small mammals (Speller et al., 1992) or variation in input applications (Wilcox et al., 2000). Depending on production costs, financial margins 
and the yield reductions on specific sites, it may be more profitable to leave such areas un-cropped if uneconomic yield reductions cannot be avoided, or if the cost of improving yields fails to produce a positive margin.

\section{Conclusion}

The current study demonstrates the impact of field position relative to boundaries and headland traffic on the establishment, development, growth and yield of spring barley, winter barley and winter wheat crops in a field survey of 40 commercial cereal fields.

The general trend of increasing yields from zones next to the field edge to in-field areas was not as expected when the machinery-related zone approach was adopted. This lower crop performance next to the field edge, irrespective of crop, region or soil texture, indicates that there are factors other than machinery traffic involved as the turning area has the most traffic. Despite the fact that the zones as determined by machinery size and working patterns were shown to impact on crop performance, there is scope for future studies to fully elucidate the factors within the zones which impacted on performance. The large number of farms which suffered headland-related crop performance constraints indicates the necessity to understand the cause of this crop effect and the opportunity for developing improved headland management. As the crop response was influenced by crop type, soil texture type and climatic subregion, management approaches may need to be tailored for individual situations.

\section{Acknowledgements}

The current project was funded by DAFM and Teagasc through the ICTAGRI Eranet. The authors wish to acknowledge the support and assistance of Luke Ashmore, Brendan Burke, Jim Grant, Aline Mouthuy, Marine Pellentz, Pierre Retailleau, Jermemie Vermes, Clara Strach, Ludovic Chauchard, Simon Laisne, Maiwenn LeMerrer, Thomas Reptin, Gwendal Marie and Romain Blanc.

\section{References}

Abdalla, Y.Y. and Fangama, I.M. 2015. Effect of shelterbelts on crop yield in Al-Rahad Agricultural Scheme, Sudan. International Journal of Current Microbiology and Applied Sciences 4: $1-4$.

Ball, B. and Douglas, J. 2003. A simple procedure for assessing soil structural, rooting and surface conditions. Soil Use and Management 19: 50-56.
Barbour, P.J., Martin, S.W. and Burger, W. 2007. Estimating economic impact of conservation field borders on farm revenue. Crop Management 6: 1-11.

Boatman, N. 1992. Effects of herbicide use, fungicide use and position in the field on the yield and yield components of spring barley. The Journal of Agricultural Science 118: 17-28.

Boatman, N. and Sotherton, N. 1988. The agronomic consequences and costs of managing field margins for game and wildlife conservation. Aspects of Applied Biology 17: 47-56.

Chamen, W.C.T., Moxey, A.P., Towers, W., Balana, B. and Hallett, P.D. 2015. Mitigating arable soil compaction: a review and analysis of available cost and benefit data. Soil and Tillage Research 146(Pt A): $10-25$.

Chaney, K., Wilcox, A., Perry, N. and Boatman, N. 1999. The economics of establishing field margins and buffer zones of different widths in cereal fields. Aspects of Applied Biology 54: 79-84.

Cook, S. and Ingle, S. 1997. The effect of boundary features at the field margins on yields of winter wheat. Aspects of Applied Biology 50: 459-466.

He, Y., Hou, L., Wang, H., Hu, K. and Mcconkey, B. 2014. A modelling approach to evaluate the long-term effect of soil texture on spring wheat productivity under a rain-fed condition. Scientific Reports 4: 5736.

Kennedy, S. 2015. Identifying Constraints to Increasing Yield Potential of Spring Barley. Doctor of Philosophy, The University of Edinburgh, Edinburgh, Scotland, UK.

Kennedy, S., Bingham, I. and Spink, J. 2017. Determinants of spring barley yield in a high-yield potential environment. The Journal of Agricultural Science 155: 60-80.

Kowalchuk, T. and Jong, E.D. 1995. Shelterbelts and their effect on crop yield. Canadian Journal of Soil Science 75: 543-550.

Kristoffersen, A.Ø. and Riley, H. 2005. Effects of soil compaction and moisture regime on the root and shoot growth and phosphorus uptake of barley plants growing on soils with varying phosphorus status. Nutrient Cycling in Agroecosystems 72: 135-146.

Kuemmel, B. 2003. Theoretical investigation of the effects of field margin and hedges on crop yields. Agriculture, Ecosystems \& Environment 95: 387-392.

Marshall, E. and Arnold, G. 1995. Factors affecting field weed and field margin flora on a farm in Essex, UK. Landscape and Urban Planning 31: 205-216.

Merrington, G., Fishwick, S., Barraclough, D., Morris, J., Preedy, N., Boucard, T., Reeve, M., Smith, P. and Fang, C. 2006. The development and use of soil quality indicators for assessing the role of soil in environmental interactions. Report to UK SIC SC030265, Environment Agency, Bristol, England, UK.

Nyéki, A., Milics, G., Kovács, A. and Neményi, M. 2013. Improving yield advisory models for precision agriculture with special regards to soil compaction in maize production. In: "Precision Agriculture'13" (ed. J.V. Stafford), Springer, Wageningen Academic Publishers, Wageningen.

Schmitz, J., Hahn, M. and Brühl, C.A. 2014. Agrochemicals in field margins - an experimental field study to assess the impacts of 
pesticides and fertilizers on a natural plant community. Agriculture, Ecosystems \& Environment 193: 60-69.

Sparkes, D., Jaggard, K., Ramsden, S. and Scott, R. 1998a. The effect of field margins on the yield of sugar beet and cereal crops. Annals of Applied Biology 132: 129-142.

Sparkes, D., Ramsden, S., Jaggard, K. and Scott, R. 1998b. The case for headland set-aside: consideration of whole-farm gross margins and grain production on two farms with contrasting rotations. Annals of Applied Biology 133: 245-256.

Speller, C., Cleal, R. and Runham, S. 1992. A comparison of winter wheat yields from headlands with other positions in five fen peat fields. In Set-aside: British Crop Protection Council Monograph 50: 47-50. Ed. J Clarke. Lavenham Press Limited, Suffolk.

Teagasc. 2018. "Teagasc - About [Online]". Available online: https:// www.teagasc.ie/ [Accessed 20 November 2018].

Unkovich, M., Baldock, J. and Forbes, M. 2010. Variability in harvest index of grain crops and potential significance for carbon accounting: examples from Australian agriculture. Advances in Agronomy 105: 173-219.

USDA. 2018. Soil Texture Calculator [Online]. Available: https:// www.nrcs.usda.gov/wps/portal/nrcs/detail/soils/research/ guide/?cid=nrcs142p2_054167 [Accessed 1207 2018].

Wilcox, A., Perry, N., Boatman, N. and Chaney, K. 2000. Factors affecting the yield of winter cereals in crop margins. The Journal of Agricultural Science 135: 335-346.

Wilson, B. 1986. Yield responses of winter cereals to the control of broad-leaved weeds. Proceedings of the European Weed Research Society Symposium - Economic Weed Control, pp. 75-82. European Weed Research Society, StuttgartHohenheim.

Wilson, P. and Aebischer, N. 1995. The distribution of dicotyledonous arable weeds in relation to distance from the field edge. Journal of Applied Ecology 32: 295-310.

Zadoks, J.C., Chang, T.T. and Konzak, C.F. 1974. A decimal code for the growth stages of cereals. Weed Research 14: 415-421. 